\title{
PHOSPHORYLATION IN VITRO OF PROTEINS IN THE PANCREAS AND PAROTIDS OF RATS: EFFECTS OF HORMONAL SECRETAGOGUES AND CYCLIC NUCLEOTIDES
}

\author{
Monique Lambert, Jean Camus and Jean Christophe \\ Department of Biochemistry and Nutrition, University of Brussels Medical School, Brussels, Belgium
}

(Receited 9 January 1975; accepted I April 1975)

\begin{abstract}
Caerulein $10^{-9} \mathrm{M}$ and carbamylcholine $5 \cdot 10^{-6} \mathrm{M}$ provoked a 3 -fold increase in amylase secretion and a $50 \%$ stimulation of protein phosphorylation in rat pancreas fragments. Secretin exerted similar effects, though more moderate, at $5 \cdot 10^{-7} \mathrm{M}$ conoentration, but was inefficient at low concentrations. Dibutyryl-cyclic AMP $2 \mathrm{mM}$ stimulated total protein phosphorylation $(+28 \%)$ but the secretory effect was subdued $\left(+50^{\circ} \%\right.$. The effects observed with cyclic GMP and its dibutyrylated derivative were insignificant. (2) In rat parotids, $10^{-5} \mathrm{M}$ isoproterenol provoked a 10-fold increase in amylase output and exerted a slight $(+15 \%)$ but significant effect on protein phosphorylation. These effects were reproduced by $0-5-20 \mathrm{mM}$ dibutyryl-cyclic AMP. Dibutyryl-cyclic GMP at a high (5 $\mathrm{mM})$ concentration allowed a slight increase $(+86 \%)$ in enzyme secretion with no apparent stimulation of protein phosphorylation. (3) These results indicate a clear stimulation of protein phosphorylation when hormonal stimulus-secretion coupling was involved in the pancreas acinar cells and parotids. The derivatives of cyclic AMP partially mimicked these effects, and more clearly so in the parotids than in the pancreas.
\end{abstract}

The mode of action of many hormones on their target cells is mediated by cyclic AMP. A hormone-responsive adenylate-cyclase (EC 4.6.1.1) increases the intracellular level of cyclic AMP, allowing the activation of protein kinases (EC 2.7.1.37) and the phosphorylation of some proteins. The alteration in the properties of these phosphoproteins appears to be responsible for the physiological effects of the hormone. The reversibility of this process is secured by the hydrolysis of cyclic AMP by phosphodiesterase(s) (EC 3.1.4.17), and by the dephosphorylation of proteins by a protein phosphatase (EC 3.1.3.16).

It also appears that the effects of some hormones, such as acetylcholine and oxytocin are mediated by cyclic GMP via a similar mechanism [1].

We undertook recently the study of the mode of action of hormones stimulating the secretion of pancreatic hydrolases by following the phosphorylation of proteins, i.e. one of the last steps of this classical scheme. In the preceding paper [2], we reported a $40-50 \%$ stimulation in the phosphorylation of total proteins after incubating pancreas fragments in the presence of $10^{-8} \mathrm{M}$ pancreozymin or $10^{-9}$ caerulein. This stimulation was significant in all subcellular fractions but the amplitude varied from one fraction to another.

In the present work, we compared the effect of caerulein, carbamylcholine, isoproterenol and cyclic nucleotides on pancreas protein phosphorylation. Parotids were utilized as a tissue of reference: the role of cyclic AMP as an intracellular messenger of isoproterenol is indeed well established in this gland [3].

\section{MATERIALS AND METHODS}

Male albino rats weighing approximately $200 \mathrm{~g}$ and fed ad lib, were anesthetized with diethyl ether. The pancreas was removed, the animal was bled by cutting a renal artery and the parotids were dissected out, successively. The pancreas and parotids were trimmed of fat, blood vessels and connective tissue. Fragments weighing approx. $20 \mathrm{mg}$ were randomly distributed in flasks containing the preincubation medium. The tissue fragments were always maintained in the presence of Trasylol Bayer $(500 \mathrm{UIK} / \mathrm{ml})$ in Krebs-Ringer bicarbonate buffer enriched with 10 $\mathrm{mM}$ glucose and adjusted to $\mathrm{pH} 7.4$ with $\mathrm{O}_{2}+\mathrm{CO}_{2}$ (95:5). The preincubation and incubation procedures, the extraction and assay of proteins, and the measurement of ${ }^{32} \mathrm{P}$ incorporation into proteins (taking into account the specific activity of inorganic phosphate) are detailed in Ref. 2, $\alpha$-Amylase in the medium was estimated by the method of Vandermeers et al. [4].

Synthetic caerulein was a gift from Farmitalia (Milano, Italy). Carbamylcholine was from Federa (Brussels, Belgium). Secretin was obtained from the GIH Research Unit of the Karolinska Institute (Stockholm, Sweden). Isoproterenol and cyclic nucleotides were purchased from Sigma (St Louis, U.S.A.). $\left[{ }^{32}\right.$ P]orthophosphate was obtained from the Institut National des Radioéléments (Mol, Belgium).

\section{RFSULTS AND DISCUSSION}

Effects of hormones on the parotids. In the parotids, $10^{-3} \mathrm{M}$ isoproterenol provoked a 10 -fold increase in amylase secretion. The parallel rise of protein phosphorylation, though moderate $(15 \%)$, was significant ( $\mathrm{P}<0-05$ ). Carbamylcholine is reported to act on parotids by liberating endogenous catecholamines [6]. Accordingly, if the phosphorylation of some proteins represents a rate-limiting step in the secretory mechanism induced by isoproterenol, then the same relationship must be observed with carbamylcholine. 
Table 1. Influence of $10^{-9} \mathrm{M}$ caerulein, $5 \cdot 10^{-6} \mathrm{M}$ carbamylcholine and $10^{-5} \mathrm{M}$ isoproterenol on amylase secretion and total protein phosphorylation.

\begin{tabular}{|c|c|c|c|c|c|}
\hline \multirow[b]{2}{*}{ Tissue } & \multirow[b]{2}{*}{$N$} & \multicolumn{2}{|c|}{ Amylase output } & \multicolumn{2}{|c|}{$\begin{array}{l}\text { Incoporation of }{ }^{32} \mathrm{P} \\
\text { into proteins }\end{array}$} \\
\hline & & Means \pm S.E. & $\begin{array}{l}\text { In } \% \text { of } \\
\text { control }\end{array}$ & Means \pm S.E. & $\begin{array}{l}\text { In } \% \text { of } \\
\text { control }\end{array}$ \\
\hline \multicolumn{6}{|l|}{ Pancreas } \\
\hline Control & 12 & $124 \pm 10$ & 100 & $24 \cdot 8 \pm 1 \cdot 1$ & 100 \\
\hline Caerulein & 12 & $389+20$ & $313^{*}$ & $37 \cdot 2 \pm 1.6$ & $150^{*}$ \\
\hline Carbamylcholine & 3 & $382 \pm 45$ & 307 . & $37 \cdot 2+3 \cdot 0$ & $150^{\circ}$ \\
\hline Isoproterenol & 3 & $162 \pm 11$ & $130 \mathrm{NS}$ & $27.9 \pm 46$ & $112 \mathrm{NS}$ \\
\hline \multicolumn{6}{|l|}{ Parotids } \\
\hline Control & 6 & $110 \pm 11$ & 100 & $24 \cdot 9+1 \cdot 3$ & 100 \\
\hline Caerulein & 3 & $119 \pm 22$ & $108^{*}$ & $21.8 \pm 2.7$ & $87 \mathrm{NS}$ \\
\hline Carbamylcholine & 3 & $359+61$ & $325^{\circ}$ & $27.8 \pm 2.0$ & $112 \mathrm{NS}$ \\
\hline Isoproterenol & 6 & $1079 \pm 64$ & 978 & $28.7+1.1$ & $115^{\circ}$ \\
\hline
\end{tabular}

Tissue fragments were preincubated at $37^{\circ}$ in order to eliminate wash-out effects (details in Ref. 2). They were transferred after $20 \mathrm{~min}$ to a fresh medium containing [ ${ }^{32} \mathrm{P}$ ] orthophosphate and when specified, a secretagogue. After 40 min incubation, the specific activity of $\mathrm{P}_{\mathrm{i}}$ was estimated in the acid-soluble extract of each sample, and the labelling of proteins was expressed in (cpm/mg proteins: $\left.\mathrm{cpm} / \mu \mathrm{g} \mathrm{P}_{\mathrm{f}}\right) \times 10^{3}$. Amylase output is expressed in $\mathrm{U}$ secreted $/ 100$ $\mathrm{mg}$ fresh weight tissue. $N$ indicates the number of experiments. $\mathrm{P}$ values $(*: \mathrm{P}<0-05)$ were calculated upon application of Student's t-test between paired data obtained with and without secretagogue. NS = not significant.

We observed that amylase secretion tripled under $5.10^{-6} \mathrm{M}$ carbamylcholine. The concomitant stimulation of protein phosphorylation was not statistically significant but this could be due to the fact that the maximal secretory capacity of the parotids was far from being attained. The effect of $10^{-9} \mathrm{M}$ caerulein on amylase secretion and protein phosphorylation were negligible in the parotids.

Effects of hormones on the pancreas. Pancreas amylase secretion was stimulated three-fold by $10^{-9} \mathrm{M}$ caerulein or $5 \cdot 10^{-6} \mathrm{M}$ carbamylcholine. Simultaneously, there was a $50 \%$ increase in total protein phosphorylation (Table 1). Neither parameter was sig-
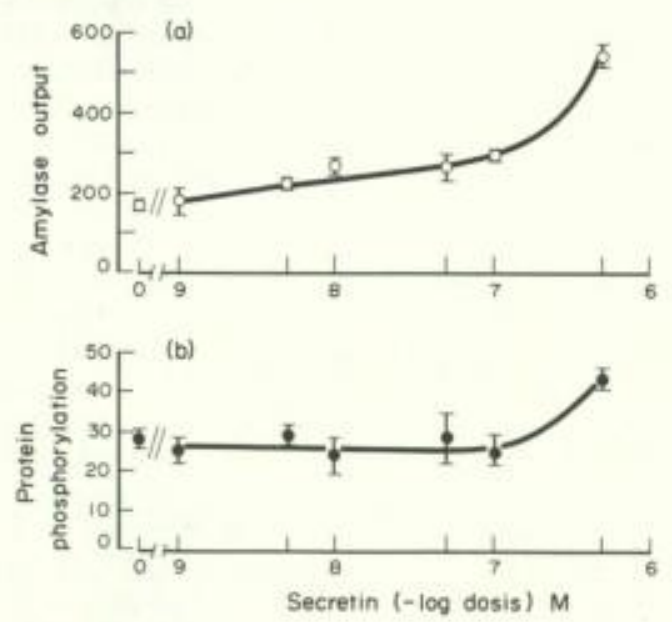

Fig. 1. Effects of increasing concentrations of secretin on amylase output and total protein phosphorylation. After 20 min preincubation, the pancreas fragments were incubated for $60 \mathrm{~min}$ in the presencse of [ $\left.{ }^{32} \mathrm{P}\right]$ orthoposphate. Means \pm S.E. of three experiments. (a) Amylase output (O) in $U$ secreted/100 mg fresh weight tissue. (b) Labelling of proteins with ${ }^{32} \mathrm{P}(\bullet)$ in ( $\mathrm{cpm} / \mathrm{mg}$ proteins: $\left.\mathrm{cpm} / \mu \mathrm{g} \mathrm{P}_{\mathrm{i}}\right)$ $\times 10^{3}$. nificantly influenced by $10^{-5} \mathrm{M}$ isoproterenol. We also tested the effects of secretin. (The main action of this hormone is to stimulate the secretion of bicarbonate and water from centro-acinar and ductular cells, and cyclic AMP appears to play the role of second messenger [5]). At concentrations lower than $10^{-7}$ M. secretin was without effect on amylase secretion and did not influence protein phosphorylation (Fig. 1), whereas 2 to 4 -fold rises in pancreas cyclic AMP levels have been observed in our laboratory with similar concentrations [5]. (However, it is clear that our method based on the extraction of total proteins could not detect a stimulation in protein phosphorylation confined to that small proportion of cells controlling bicarbonate secretion). At a very high $\left(5 \times 10^{-7} \mathrm{M}\right)$ concentration, secretin markedly stimulated amylase secretion and this time there was a $22 \%$ increase in total protein phosphorylation. This pancreozyminlike effect could be due either to a contamination of the Karolinska preparation of secretin by pancreozymin, or to the action of high doses of secretin on acinar cells.

Effects of cyclic mucleotides. The preceding results show a positive correlation between large effects of hormones on amylase secretion and protein phosphorylation in two target organs: the exocrine pancreas and the parotids. They suggest the activation of protein kinases by a second messenger. This intracellular mediator has been identified as cyclic AMP in the case of isoproterenol stimulating the parotids [3] and of secretin acting on the centro-acinar cells of the pancreas [7]. The messenger of pancreozymin is not yet identified since it is difficult to assign such a role to cyclic AMP. Indeed, the levels of cyclic AMP increase only under very high concentrations of pancreozymin, far above those provoking definite amylase hypersecretion [5]. The activity in vitro of adenylate-cyclase in pancreas homogenates is sensitive to pancreozymin $[8,9]$ but theophylline and dibutyrylcyclic AMP do not reproduce the secretory effect in 
Table 2. Influence of cyclic nucleotides on amylase secretion and total protein phosphorylation

\begin{tabular}{|c|c|c|c|c|c|}
\hline \multirow[b]{2}{*}{ Tissue } & \multirow[b]{2}{*}{$N$} & \multicolumn{2}{|c|}{ Amylase output } & \multicolumn{2}{|c|}{$\begin{array}{l}\text { Incorporation of }{ }^{32} \mathrm{P} \\
\text { into proteins }\end{array}$} \\
\hline & & Means \pm S.E. & $\begin{array}{l}\text { In } \% \text { of } \\
\text { control }\end{array}$ & Means \pm S.E. & $\begin{array}{l}\text { In } \% \text { of } \\
\text { control }\end{array}$ \\
\hline \multicolumn{6}{|l|}{ Pancreas } \\
\hline $\begin{array}{l}\text { Control } \\
\text { Dibutyryl-cyclic }\end{array}$ & 16 & $128 \pm 6$ & 100 & $36-4 \pm 1 \cdot 1$ & 100 \\
\hline $\begin{array}{l}\text { AMP } 0.5 \mathrm{mM} \\
\text { Dibutyryl-cyclic }\end{array}$ & 4 & $170 \pm 16$ & $133 \mathrm{NS}$ & $42 \cdot 2 \pm 4 \cdot 3$ & $116 \mathrm{NS}$ \\
\hline AMP $2 \mathrm{mM}$ & 6 & $197 \pm 20$ & $154^{*}$ & $46-6 \pm 20$ & $128^{*}$ \\
\hline Cyclic GMP $1 \mathrm{mM}$ & 3 & $156 \pm 15$ & $122 \mathrm{NS}$ & $44 \cdot 3 \pm 10 \cdot 6$ & $122 \mathrm{NS}$ \\
\hline $\begin{array}{l}\text { Cyclic GMP } 5 \mathrm{mM} \\
\text { Dibutyryl-cyclic }\end{array}$ & 3 & $212 \pm 23$ & $166 \mathrm{NS}$ & $37 \cdot 2 \pm 3 \cdot 5$ & $102 \mathrm{NS}$ \\
\hline GMP $5 \mathrm{mM}$ & 2 & $125 \pm 9$ & $97 \mathrm{NS}$ & $45 \cdot 2 \pm 2 \cdot 6$ & 124 \\
\hline Theophylline $10 \mathrm{mM}$ & 4 & $173 \pm 16$ & $135 \mathrm{NS}$ & $39.7 \pm 3.4$ & $109 \mathrm{NS}$ \\
\hline \multicolumn{6}{|l|}{ Parotids } \\
\hline $\begin{array}{l}\text { Control } \\
\text { Dibutyryl-cyclic }\end{array}$ & 6 & $179 \pm 9$ & 100 & $35 \cdot 3 \pm 2 \cdot 3$ & 100 \\
\hline $\begin{array}{l}\text { AMP } 0.5 \mathrm{mM} \\
\text { Dibutyryl-cyclic }\end{array}$ & 3 & $1408 \pm 72$ & $787^{*}$ & $45.5 \pm 1.8$ & $129^{*}$ \\
\hline AMP $2 \mathrm{mM}$ & 3 & $1567 \pm 102$ & $876^{*}$ & $45-4 \pm 3 \cdot 6$ & $129^{*}$ \\
\hline Cyclic GMP $1 \mathrm{mM}$ & 3 & $224 \pm 11$ & $125 \mathrm{NS}$ & $38.5 \pm 1.8$ & $109 \mathrm{NS}$ \\
\hline Cyclic GMP $5 \mathrm{mM}$ & 3 & $333 \pm 35$ & $186^{*}$ & $36.7 \pm 3.5$ & 104 NS \\
\hline
\end{tabular}

After $20 \mathrm{~min}$ preincubation, the tissue fragments were incubated for $60 \mathrm{~min}$ in the presence of $\left[{ }^{32} \mathrm{P}\right]$ orthophosphate. Same presentation of data as in Table 1 .

vitro of pancreozymin on tissue fragments (Ref. 10 and Table 2).

Effects of cyclic mucleotides on the parotids. The effects of cyclic nucleotides on protein phosphorylation and enzyme secretion from the parotids were consistent with the model. Indeed, 0.5 or $200^{\circ} \mathrm{mM}$ dibutyryl-cyclic AMP $\left(N^{6}, O^{2}\right.$-dibutyryl adenosine $3^{\prime}, 5^{\prime}$-monophosphate) reproduced the secretory effect of isoproterenol (an 8 to 9-fold increase in amylase output) and stimulated protein phosphorylation by $29 \%$ (Table 2). Cyclic GMP did not stimulate amylase secretion at a $1 \mathrm{mM}$ concentration. A high $(5 \mathrm{mM})$ concentration allowed a slight $(+86 \%)$ but significant effect, without accompanying increase in protein phosphorylation. This modest effect of $5 \mathrm{mM}$ cyclic GMP could be due to the low sensitivity of cyclic AMP dependent protein kinases to cyclic GMP $[11,12]$ and/or to the inhibitory effect exerted by high concentrations of cyclic GMP on cyclic AMP phosphodiesterase(s) [13].

Effect of cyclic nucleotides on the pancreas. Dibutyryl-cyclic AMP at a $2 \mathrm{mM}$ concentration significantly stimulated amylase output and total protein phosphorylation. However, the secretory effect was limited $(+50 \%)$ when compared to the much larger (3-fold) stimulation by caerulein $10^{-9} \mathrm{M}$, and this in spite of the fact that the gross enhancement of protein phosphorylation observed with both caerulein and dibutyryl-cyclic AMP was of the same order of magnitude in paired fragments.

Theophylline had no effect on amylase secretion and protein phosphorylation (Table 2) in spite of the 2-fold increase in cyclic AMP levels ordinarily observed in pancreas fragments submitted to the same $10 \mathrm{mM}$ concentration of the methylxanthine [9].
The results observed with cyclic GMP and dibutyryl-cyclic GMP $\left(N^{6}, O^{2}\right.$-dibutyryl guanosine 3',5' monophosphate) were dubious. They do not support a decisive role of cyclic GMP in enzyme secretion but their inconsistency could be due to poor tissue permeability to the cyclic derivatives of guanosine monophosphate.

We may conclude that the results obtained with the parotid agree well with the model of a cAMP mediated action of isoproterenol.

In the pancreas, we found a good correlation between the hormonal stimulation of enzyme secretion and increased protein phosphorylation. However, DB cAMP could only partially reproduce the effects of caerulein or carbamylcholine on amylase secretion and protein phosphorylation while theophylline had no significant effects on both parameters. Therefore we may not conclude at this state of the experiments that CAMP is the intracellular mediator of caerulein or carbamylcholine.

We hope that the study of pancreatic adenylate cyclase, which is now in progress in our laboratory, together with the present results, will enable us to understand the mode of action of hormonal secretagogues on the pancreas.

Acknowledgements - This work was supported by Fonds de la Recherche Scientifique Médicale (Belgium), contract number 20,403. We wish to express our thanks to Dr. Karim (Farmitalia, Brussels) and Dr. Wald (Bayer-Belgium) for generous gifts of cacrulein and Trasylol.

\section{REFERENCES}

I. N. D. Goldberg. M. K. Haddox, D. K. Hartle and J. W. Hadden, Pharmacology and the Future of Man 5. $146(1973)$. 
2. M. Lambert, J. Camus and J. Christophe, Biochem. biophys. Res. Commun. 52, 935 (1973).

3. H. Babad, R. Ben-Zvi, A. Bdolah and M. Schramn, Eur. J. Biochem. 1, 96 (1967).

4. A. Vandermeers, M. C. Vandermeers-Piret and J. Christophe, Biochimie 53, 859 (1971).

5. M. Deschodt-Lanckman, P. Robberecht, P. De Neef and J. Christophe, Gastroenterology, in press.

6. M. Schramm, Biochim. biophys. Acta 165, 546 (1968)-

7. R. M. Case, M. Johnson. T. Scratcherd and M. S. A. Sherratt, J. Physiol., Lond. 223, 669 (1972).

8. W. J. Rutten, J. J. H. H. De Pont and S. L. Bonting. Biochim. biophys. Acta 274, 201 (1972).
9. P. Robberecht, Ph.D. Thesis, University of Brussels Medical School (1974)

10. H. Bauduin, L. Rochus, D. Vincent and J. E. Dumont, Biochim. biophys. Acta 252, 171 (1971).

II. E. Miyamoto, J. F. Kuo and P. Greengard, J. biol. Chem. 244, 6395 (1969).

12. F. Labric, S. Lemaire and C. Courte, J. biol. Chem. 246, 7293 (1971)

13. P. Robberecht, M. Deschodt-Lanckman, P. De Neef and J. Christophe, Eur. J. Biochem. 41, 585 (1974).

14. P. Robberecht, M. Deschodt-Lanckman, P. De Neef and J. Christophe, FEBS Lett. 43, 139 (1974). 